\title{
PERHITUNGAN JUMLAH BAKTERI ESCHERICHIA COLI DENGAN PENGOLAHAN CITRA MELALUI METODE THRESHOLDING DAN COUNTING MORPHOLOGY
}

\author{
${ }^{1)}$ Ari Purno Wahyu Wibowo, ${ }^{2)}$ Rian Andrivani \\ ${ }^{1)}$ Universitas Widyatama, Jl.Cikutra No.204 A Bandung 40124 \\ ${ }^{2)}$ STMIK “Amik Bandung”, Jl.Ters Jakarta No 28 Bandung \\ 1)ari.purno@widyatama.ac.id, ${ }^{2)}$ rianandrivani@gmail.com
}

\begin{abstract}
Abstrak
Salah satu permasalahan yang terdapat di bidang kesehatan adalah tingkat tingginya kontaminasi bakteri pada makanan yang dijual/disajikan oleh pihak penjual, mulai dari Pedagang Kaki Lima (PKL), restoran, dan industri makanan. Jika makanan kita terkontaminasi bakteri akan memberikan dampak negatif bagi kita dan masyarakat yang mengonsumsi makanan terkontaminasi. Dan salah satu alasan makanan tersebut terkontaminasi karena adanya bakteri yang tumbuh pada makanan tersebut yang melebihi batas pencemaran maksimum. Salah satu bakteri yang dapat menyebabkan makanan tersebut terkontaminasi adalah bakteri Escherichia coli.
\end{abstract}

Salah satu solusi yang dapat diambil yaitu, dengan menyediakan sistem perhitungan bakteri Escherichia coli. Dimana dengan sistem tersebut dapat mengetahui berapa jumlah bakteri Escherichia coli yang terdapat pada makanan yang diteliti agar diketahui apakah makanan tersebut layak dijual atau tidak berdasarkan jumlah batas pencemaran maksimum dengan jumlah bakteri yang mencemari makanan yang diteliti. Dalam perkembangbiakannya bakteri ini dapat tumbuh secara morfological dimana bakteri ini tumbuh secara acak dengan bentuk yang sama yaitu dalam bentuk batang namun tumbuh dengan posisi secara acak.

Dalam perancangan system tersebut penulis menggunakan bahasa pemrograman $\mathrm{C}$ disertai dengan perangkat lunak yang membantu dalam pembuatannya yaitu Matlab. Setelah implementasi sistem ini akan diuji coba hasilnya adalah para ahli industi makanan dapat menentukan apakah makanan yang diteliti tersebut layak dijual atau tidak sesuai dengan tingkat pencemaran yang terdapat pada makanan tersebut.
Kata Kunci: Bakteri Escherichia coli. Morphological, Makanan, Perhitungan bakteri

\section{Abstract}

One of the issues contained in the health sector is the high level of bacterial contamination of food sold or served by the sellers from the street food restaurants and the food industry. If our food contaminated with the bacteria will adversely affect us and the people who eat contaminated foods. And one of the reasons that food contaminated by bacteria that grow on the food that exceeds the maximum contamination limit. One of the bacteria that can cause food that is contaminated with the bacteria Escherichia coli.

One solution that can be taken is, by providing the calculation system of Escherichia coli. Where in the system can determine how the number of Escherichia coli bacteria found in foods studied in order to know whether the food is decent for sale or not based on the amount of the maximum contamination limit to the number of bacteria that contaminate food studied. In the breeding of bacteria can grow morfological where these bacteria grow randomly with the same shape in the form of rods but growing at random positions.

In designing the system, the author uses the $\mathrm{C}$ programming language comes with software that helps and using in Matlab. After implementation of this system will be tested the result is the food industry, experts can determine whether the foods studied eligible or not for sale according with the level of pollution contained in these foods.

Keywords: Bacterai Escherichia coli. Morphological, foods, calculation 


\section{Pendahuluan}

Kesehatan adalah hal yang sangat penting bagi kelangsungan hidup manusia salah satu cara memperoleh kesehatan adalah dengan memberi nutrisi pada tubuh misalnya dengan asupan makanan. Namun makanan yang dijual oleh para pedagang belum tentu terjamin kesehatan dan kebersihannya, seperti makanan yang telah terkontaminasi oleh bakteri Escherichia coli yang dapat membahayakan organ tubuh manusia. Apabila makanan yang dikonsumsi sudah terkontaminasi oleh bakteri ini yang tumbuh pada makanan tersebut dengan jumlah diluar batas maksimum pencemaran makanan.

Sebenarnya bakteri Escherichia coli ini memiliki manfaat tersendiri bagi tubuh manusia diantaranya bakteri ini berfungsi untuk menekan pertumbuhan bakteri jahat, selain itu bakteri ini pun dapat membantu dalam proses pencernaan sisa-sisa makanan pada usus besar manusia. Fungsi utama bakteri ini adalah membantu vitamin $\mathrm{K}$ pada proses pembusukan sisa-sisa makanan, namun dalam jumlah yang besar bakteri ini dapat menimbulkan bahaya seperti diare dan dapat membuat beberapa organ tubuh manusia terinfeksi.

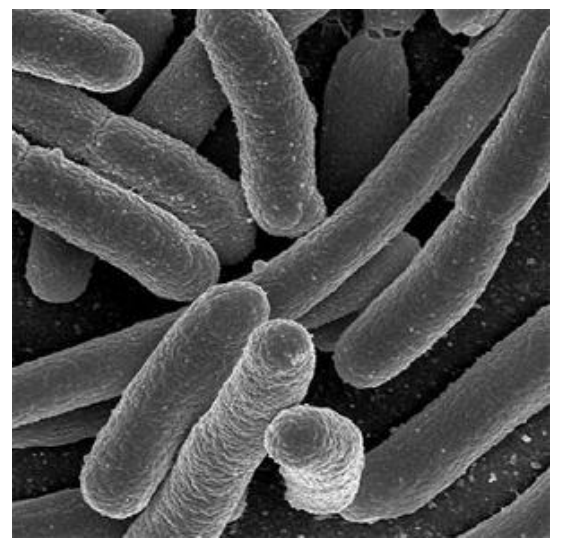

Gambar 1. Bakteri Escherichia coli

Untuk menentukan berapa jumlah maksimum bakteri Escherichia coli Badan Standarisasi Nasional (BSN) pada SNI 7388:2009 telah menetapkan batas maksimum tingkat pencemaran suatu makanan oleh bakteri ini, yaitu $1 \times 10^{2} \mathrm{MPN} / \mathrm{g}$, melalui perhitungan Most Probable Number (MPN) (Juwita Usna; Haryani Yuli; Jose Christine, 2014)

Untuk saat ini perhitungan jumlah bakteri masih belum dilakukan secara komputerisasi. Perhitungan bakteri saat ini masih dilakukan secara manual dimana para ahli menggunakan dua cara untuk menghitung jumlah bakteri yaitu perhitungan langsung dan tidak langsung (Jiwanjaya Yoga , 2016)

\section{I.1 Identifikasi Masalah}

Berdasarkan latar belakang di atas, penulis mengidentifikasikan beberapa masalah yang ada sebagai berikut :

1. Belum ditemukan metode perhitungan komposisi bakteri secara otomatis yang dapat memudahkan para ahli.

2. Jumlah bakteri yang terdapat pada suatu produk makanan masih dilakukan perhitungan secara manual, sehingga para ahli di bidang industri makanan cukup kesulitan menentukan tingkat pencemaran yang disebabkan oleh banyaknya jumlah bakteri pada makanan tersebut.

3. Dengan perhitungan manual yang dilakukan seperti sekarang, untuk menentukan berapa jumlah detail bakteri yang diteliti sangatlah sulit dikarenakan perhitungan dilakukan dengan mencampuradukan antara bakteri yang masih hidup dan bakteri yang telah mati.

\section{I.2 Rumusan Masalah}

Rumusan masalah yang akan dibahas adalah sebagai berikut:

1. Bagaimana membangun sistem perhitungan bakteri secara otomatis dengan akurat dan cepat yang dapat memudahkan kinerja para peneliti bakteri Escherichia coli?

2. Bagaimana membangun sistem perhitungan bakteri otomatis dengan metode Threshoding dan Counting Morphology?

\section{I.3 Batasan Masalah}

Batasan masalah bertujuan untuk memberikan arah serta untuk menyederhanakan dan membatasi permasalahan. Batasan masalah dari penelitian ini adalah sebagai berikut :

1. Bakteri dalam penelitian ini hanya melibatkan bakteri Escherichia coli.

2. Penelitian yang dilakukan hanya menghitung jumlah bakteri tanpa ada proses lanjutan.

3. Adapun data yang diambil untuk dijadikan penelitian yakni berupa sebuah video. 


\section{I.4 Maksud dan Tujuan Penelitian}

Adapun maksud dari penelitian ini adalah membangun system perhitungan jumlah bakteri Escherichia coli secara otomatis.

Tujuan yang ingin dicapai melalui penelitian ini adalah untuk menghasilkan sebuah sistem yang dapat memberikan tanda pada setiap objek bakteri Escherichia coli yang muncul. Menghasilkan sistem perhitungan bakteri Escherichia coli dengan tingkat hasil keakuratan yang cukup tinggi.

\section{I.5 Manfaat Penelitian}

Manfaat sistem perhitungan bakteri secara otomatis ini diharapkan dapat mempermudah para peneliti bakteri Escherichia coli sehingga para peneliti dapat dengan mudah mengambil sebuah tindakan lanjutan.

\section{LANDASAN TEORI}

\section{II.1 Pengertian Bakteri}

Makhluk hidup bersel satu prokariotik, yaitu sel yang tidak memiliki membran Nukleus (Inti sel). Bakteri dapat hidup bebas dan dapat ditemukan di beberapa lingkungan seperti udara, tanah, debu, air dalam tubuh manusia bahkan hewan nama bakteri berasal dari bahasa Yunani dari kata bacterion yang berarti batang kecil (Imam., 2016). Berikut merupakan struktur sel dari bakteri :

\section{Kapsul (Kapsula)}

Kapsula adalah lapisan mukus (lendir) yang melapisi sel da terbentuk dari hasil metabolisme sel Kapsula berfungsi untuk menempel pada substrat dan memberikan resistensi dan perlindungan terhadap sistem pertahanan inang. Kapsula bergelatin juga sebagai pengikat antara sel-sel pada bakteri untuk membentuk koloni

\section{Dinding sel}

Dindingsel disebut sel ini bersifat juga peptidoglikan atau murein dinding tebal dan kaku sehingga berfungsi untuk mempertahankan bentuk sel, perlindungan fisik/mekanis, dan menjaga agar sel tidak pecah dalam media hipertonis (lebih kental).
3. Membran Plasma

Membran plasma tersusun dari senyawa fosfolipid dan protein yang bersifat selektif permeabel atau (bisa zat-zat tertentu). Fungsinya untuk membungkus sitoplasma, serta mengatur pertukaran dengan zat yang ada zat yang berada di dalam sel diluar sel.

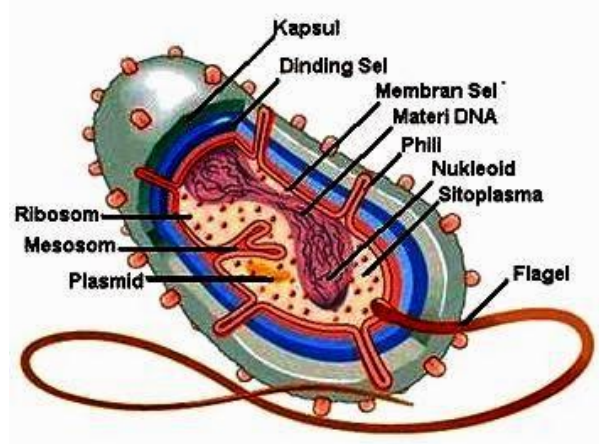

Gambar 2. Struktur sel Bakteri

4. Mesosom

Mesosom adalah organel sel yang memiliki sitoplasma penonjolan pada membran plasma ke arah dalam. Fungsinya untuk menghasilkan energi, membentuk dinding sel menerima DNA pada saat terjadi pembelahan sel dan konjugasi.

5. Sitoplasma

Sitoplasma bakteri adalah cairan organik seperti lemak atau disebut juga koloid yang mengandung molekul protein, karbohidrat, dan garam-garam mineral, enzim, DNA, ribosom klorosom, yang sebagai tempat metabolisme sel saat terjadinya reaksi-reaksi.

6. Ribosom

Ribosom adalah organel-organel kecil sitoplasma RNA (ribonukleic acid)yang tediri dari senyawa protein dan Jumlah ribosom di dalam suatu sel bakteri mencapai ribuan agar mensintesis protein.

7. DNA (Deoxyribonucleic acid)

Berdasarkan fungsinya, bakteri memiliki 2 macam DNA, yaitu: 
a. Kromosom DNA adalah materi genetik yang menentukan sebagian besar dari sifat-sifat metabolisme bakteri.

b. DNA non-kromosom hanya menentukan sifat-sifat tertentu, (plasmid) yang sifat patogen, kemampuan dalam bereproduksi secara seksual, atau sifat fertilitas dan sifat kekebalan terhadap zat antibiotik tertentu.

8. Vakuola Gas

Dengan mengatur jumlah gas dalam bakteri dapat meningkatkan atau mengurang vakuola gasnya, kepadatan sel mereka secara keseluruhan dan bergerak ke atas atau ke bawah dalam air.

9. Granula Gas

Granula gas berfungsi sebagai tempat penyimpanan cadangan makanan atau senyawasenyawa lain yang dihasilkannya.

10. Klorosom

Klorosom adalah suatu struktur lipatan yang ada di bawah membran pigmen fotosintetik plasma yang berisi klorofil dan lainnya. Fungsinya adalah untuk fotosintesis yang hanya terdapat pada bakteri fotosintetik.

11. Flagela

Flagela adalah struktur kompleks yang tersusun atas bermacam-macam protein termasuk membuat flagela flagelin yang berbentuk seperti tabung cambuk dan protein kompleks yang memanjangkan dinding sel dan membran yang menyebabkan flagela berotasi untuk membentuk motor. Flagela berbentuk seperti cambuk. Flagela digunakan bakteri sebagai alat gerak.

\section{Fimbrian}

Fimbria adalah tabung protein yang menonjol dari membran pdaada banyak spesies dari Proteobacteria. Dan terdapat pada semua sel bakteri. Fimbria hanya ditemukan pada bakteri gram negatif, dimana peptidoglikan tersebut memiliki lapisan yang tipis pada dinding bakteri selnya.

\section{Pili}

Struktur pili mirip sel bakteri dengan fimbria dan ada di permukaan namun tidak banyak. Pili berperan dalam konjugasi bakteri.

\section{Plasmid}

Plasmid dapat dengan mudah didapat oleh bakteri Pada umumnya bakteri memiliki plasmid.Namun, bakteri juga mudah dalam bentuk transfer gen horizontal.

\section{II.2 IMAGE PROCESSING}

Teknik pembacaan berdasarkan image prosessing bisa didesain secara otomatis untuk mengklasifikasikan beberapa jenis bakteri, image bakteri bisa di perjelas dengan mengurangi gambar noise yang ada pada latar belakang image. Dengan menggunakan algoritma image processing data backteri bisa ditampilan secara statistik langkah pertama adalah dengan mengisolasi cell bakteri dari data background atau dikenal dengan teknik segmentasi warna (Bo Yang Yu; Caglar Elbuken;Carolyn L. Ren; Jan P. Huissoon, 2011).

Proses meningkatkan atau menajamkan sebuah image dengan metode threshold bisa membaca jumlah cell yang saling berdekatan dan sangat banyak. Pengambilan gambar dengan image processing bisa menggunakan mikroskop dengan pengambilan gambar rata-rata $20 \mathrm{x} 20$, bisa mengahailkan jumlah pixel pada background yang akan dihilangkan, metode ini dikenal dengan generalized euclidean distance (GED) atau disebut juga mahalonibit distance (MD) (O. Dzyubachyk; W. A. van Cappellen; J. Essers;W. J. Niessen;, 2010).

\section{II.3 METODE THRESHOLDING}

Suatu metode Thresholding merupakan cara yang digunakan untuk memisahkan antara objek dan latar belakangnya (Background). Thresholding merupakan teknik yang cukup efektif untuk proses segmentasi citra. Melalui metode Thresholding ini sistem dapat membedakan mana objek yang dianggap harus dihitung dan mana latar belakang (Background) (Gonzalez, R. C;Woods, R. E.,, 2002).

\section{II.4 COUNTING MORPHOLOGY}

Counting Morphology adalah metode yang dikembangkan untuk menjadikan proses morfologi berfungsi agar dapat melakukan proses perhitungan. Melalui metode Counting Morphology, sistem akan mendeteksi setiap objek bakteri yang muncul 
berdasarkan rentang waktu tertentu dan setelah pendeteksian berakhir, sistem akan mengkalkulasikan berapa objek yang terhitung, lalu menampilkan hasil perhitungan yang telah diproses.

\section{II.5 ESCHERICHIA COLI}

Escherichia coli adalah nama sejenis bakteri yang hidup di dalam usus hewan dan manusia. Meskipun sebagian besar jenis E. coli tidak berbahaya, namun ada beberapa jenis yang dapat merugikan manusia. Diberi nama berdasarkan penemunya Theodor Escherichia, Escherichia coli adalah bakteri Gram Escherichia coli tumbuh di usus bawah endotermik organisme berdarah panas (Citra, 2016).

Bakteri ini dapat memberikan beberapa manfaat bagi manusia diantaranya dapat menekan pertumbuhan bakteri jahat pada usus besar manusia dan juga membantu dalam proses pencernaan usus besar manusia termasuk pembusukan sisa-sisa makanan dalam. Manfaat lain dari bakteri ini yaitu dapat membantu memproduksi vitamin $\mathrm{K}$ melalui proses pembusukan sisa makan. Vitamin K berfungsi ntuk pembekuan darah misalkan saat terjadi.

Dalam jumlah yang berlebihan bakteri ini dapat mengakibatkan diare (Saputra; Rochmat, 2013), dan bila bakteri ini menjalar dan dapat menyebabkan infeksi pada tubuh. Seperti kencing dapat mengakibatkan infeksi saluran kemih/kencing pada saluran kencing (Putra, 2016)

Selain akibat terdapat beberapa dampak negatif dari bakteri ini :

\section{Infeksi Otak (Meningitis)}

Infeksi otak\} yang disebabkan oleh E.coli umumnya terjadi pada bayi, dengan gangguan saraf, kuning gejala demam, dan pertumbuhan, pada tubuh, penurunan asupan makanan, dan periode henti napas. Pada bayi gejala berupa rewel di bawah umur 1 tahun, tampak mengantuk terus - menerus, muntah, tidak nafsu makan, dan kejang. Gejala pada orang dewasa antara lain nyeri kepala, muntah, bingung dan penurunan kesadaran

2. Infeksi Paru-paru (Pneumonia)

Pada penderita pneumonia E.coli didapatkan demam, peningkatan lendir, jalan napas dan cepat

3. Infeksi pada rongga perut
Infeksi pada kantung dan saluran empedu (kolelitiasis, kolangitis) menimbulkan gejala demam tinggi dengan atau tanpa menggigil, nyeri pada perut kanan atas, dan kuning pada tubuh. Pada infeksi berat, dapat terjadi penurunan tekanan darah dan penurunan kesadaran. Selain itu, E.coli dapat menyebabkan infeksi dengan kumpulan nanah (abses) pada rongga perut dengan gejala demam tidak tinggi dan nyeri perut (Natharina, 2016)

\section{Metodologi Penelitian}

Pada bab ini akan dijelaskan mengenai kerangka penelitian dan langkah - langkah penelitian dalam mendeteksi objek bergerak yaitu bakteri pada video pengolahan citra dengan metode Thresholding dan Counting Morphology

\section{III.1 Tahapan Metodologi Penelitian}

Untuk menjelaskan sistem yang dibuat oleh penulis akan dijelaskan dalam diagram alur sebagai berikut :

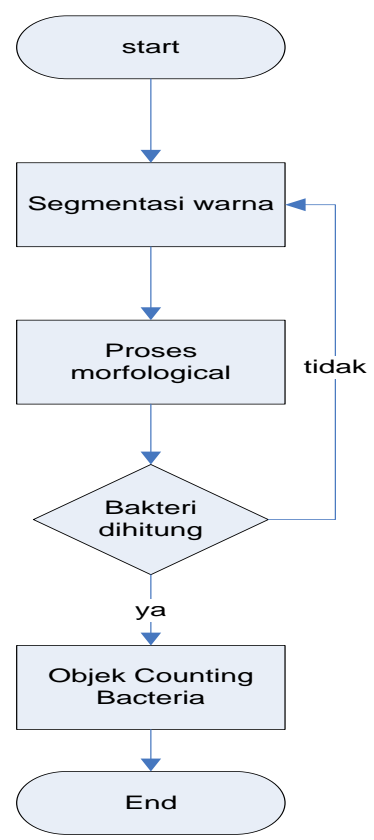

Gambar 3. Metode Penelitian

1. Segmentasi warna

pada metode ini data dipisahkan dalam dua bagian, dibuat penajaman warna dan area, 
objek yang tidak terpakai akan dihilangkan,algoritma segmentasi warna menggunakan dua metode discontinuity and similarity

2. Proses Morfological

Pada tahapan morfological menggunakan teknik image processing dengan teknik penajaman gambar, metode yang digunakan adalah morfological dilasi.

3. Proses Penajaman Warna

Pada tahapan ini objek yang sudah tajamkan dengan menghilangkan noise yang ada pada background objek dari bacteri dihitung dengan metode Bounding Box Output Port sehingga bacteri yang terhitung diberi marker agar sistem bisa terus menghitung jika ada penambahan bacteria

\section{Analisis dan Perancangan}

Pada bab ini akan dijelaskan mengenai analisis sistem perhitungan bakteri yang pernah digunakan oleh para ahli. Berdasarkan hasil pengumpulan data yang di dapat oleh penulis dari berbagai sumber, penulis mendapatkan informasi tentang cara perhitungan bakteri. Untuk dapat menentukan jumlah bakteri, para peneliti biasa menggunakan dua cara, yaitu metode perhitungan bakteri dengan metode secara langsung dan tidak langsung. Berikut merupakan penjelasan dari kedua metode perhitungan bakteri tersebut

\section{IV.1 Perhitungan Jumlah Bakteri Secara Langsung}
a. Counting Chamber
- Centrifuge
- Turbidimetri (Kekeruhan)
- Electronic C
- Counter (Perhitungan Elektronik)
- Analisis senyawa Kimia
- Analisa Berat Kering
- Pengenceran
- $\quad$ Most Probable Number (MPN)
- Metode Cawan
- Jumlah Koloni

b. Cara Pengamatan Mikroskopik

\section{c. Filter Membran}

\section{IV.2 Perhitungan Jumlah Bakteri Secara Tidak langsung}

Jumlah bakteri dihitung secara keseluruhan baik yang mati atau yang hidup atau hanya untuk menentukan jumlah mikroba yang hidup saja, ini tergantung cara-cara yang digunakan. Untuk menentukan jumlah bakteri yang hidup dapat dilakukan setelah larutan bahan atau biakan bakteri diencerkan dengan faktor pengenceran tertentu dan ditumbuhkan dalam media dengan cara-cara tertentu tergantung dari macam dan sifat-sifat bakterinya.

Jumlah bakteri masih belum mendekati hasil maksimal, dikarenakan setiap cara perhitungan diatas masih ada kelemahan masing-masing mulai dari perhitungan yang melibatkan sel hidup dan sel mati bakteri, keterbatasan alat, keperluan persiapan yang cukup panjang, ketelitian penelitian dan lain-lain. Untuk menjawab persoalan diatas, maka penulis membuat solusi dengan membangun sebuah sistem perhitungan bakteri yang dapat memberikan tanda (Mark) terhadap bakteri yang muncul pada setiap rentang waktu tertentu, sehingga setiap bakteri yang tumbuh bertambah banyak, sistem akan selalu memberi tanda (Mark) pada setiap bakteri yang muncul Setelah pendeteksian objek bakteri selesai, sistem akan mengkalkulasikan jumlah keseluruhan bakteri yang terdeteksi.

Diharapkan dengan sistem perhitungan bakteri secara otomatis yang diusulkan oleh penulis ini dapat memudahkan kinerja para peneliti bakteri, khususnya bakteri Escherichia coli. Dengan adanya sistem perhitungan bakteri secara otomatis ini, para peneliti bisa mengetahui jumlah pasti bakteri yang dihitung tanpa harus mengeluarkan banyak peralatan, biaya dan tenaga serta menghemat waktu untuk kepentingan penelitian bakteri ini

\section{Tahapan Perancangan Sistem}

Berikut ini akan dijelaskan tahapan perancangan sistem pengambilan data bacteri diambil dalam bentuk data image atau vidio hasil pengamatan dari sample makanan menggunakan mikroskop digital data tersebut bisa direkam dalam file film dengan format mp4 sehingga data hasil pengamatan bisa disimpan dan digunakan untuk penelitian selanjutnya

Pada tahapan thresholding data bacteria akan dianalisa dengan menghilangkan gambar background 
pada critra bakteria fungsi thresholding adalah untuk menghilangkan image noise dan dirubah kedalam tampilan abu abu sehingga gambar bacteri dan background terlihat jelas. Kemudian pada metode counting Morfologi jumlah bacteri secara otomatis akan terhitung dan diberi tanda oleh sistem atau mark berwarna hijau, sehingga penambahan jumlah bacteri bisa terus dimonitoring apakah masuk ke dalam batas jumlah normal atau tidak

\section{Sample Data}

Pada proses awal pembuatan sistem ini dilakukan pengumpulan sample data. Sample data ini berupa sample video, karena pada penelitian ini objek yang akan dideteksi bersumber dari sebuah video,penelitian dapat dilakukan dengan menggunakan sample tersebut.

\section{Metode Thresholding}

Pada kode program matlab dibawah berfungsi untuk merubah dan menkonversi sebuah citra biner dengan fungsi im2bw menjadi level treshlold

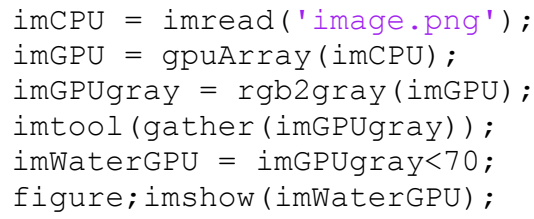

pada metode tresholding pixel image akan yang memiliki nilai 0 aka diganti dengan 1 dari hasil citra biner yang telah dikonversi sebelumnya pada mode grayscale

\section{Metode Counting Morphology}

Metode morfologi adalah sebuah cara untuk mengektrasi sebuah citra yang merepresentasikan sebuah objek dalam bentuk area lain dengan variable boundaries, skeleton dan convex, morfologi bisa disebut sebagai suatu teknik untuk merubah bentuk pada suatu citra, teknik yang digunakan pada metode ini adalah erosi dan dilasi.

\section{Vi. Pembahasan}

Pada pembahasan ini penulis menggunakan salah satu teknik morpological denga metode dilate dengan mengghilangkan noise atau background pada gambar objek yang tidak digunakan dengan menggunakan dua properti.

\section{VI.1 Propery Neighborhoodsource}

Proses penghilangan background image berdasarkan inputan data dan proses perhitungan pada image lebih spesifikasi, jika variable data memenuhi property dari algoritma dilasi atau clone maka objek dari gambar bakteri akan dihitung kembali.

\section{VI.2 Neighborhood}

Proses pembacaan dari nilai elemen dimana pengaturan dlakukan oleh algoritma clone dengan perubahan properti matrik dari 0 dan 1 hasil dari clone dilasi bisa dilihat pada tabel 1 .

\section{VI.3 Pengaturan Property Vision Blob Analysis}

Proses property blob analisis disini untuk menampilkan grafik komputasi dari data image yang telah dirubah dalam bentuk biner berdasarkan data spesifikasi bebarapa property yang digunakan seperti pada tabel 2

Tabel 1. Proses Morpologicaldilate

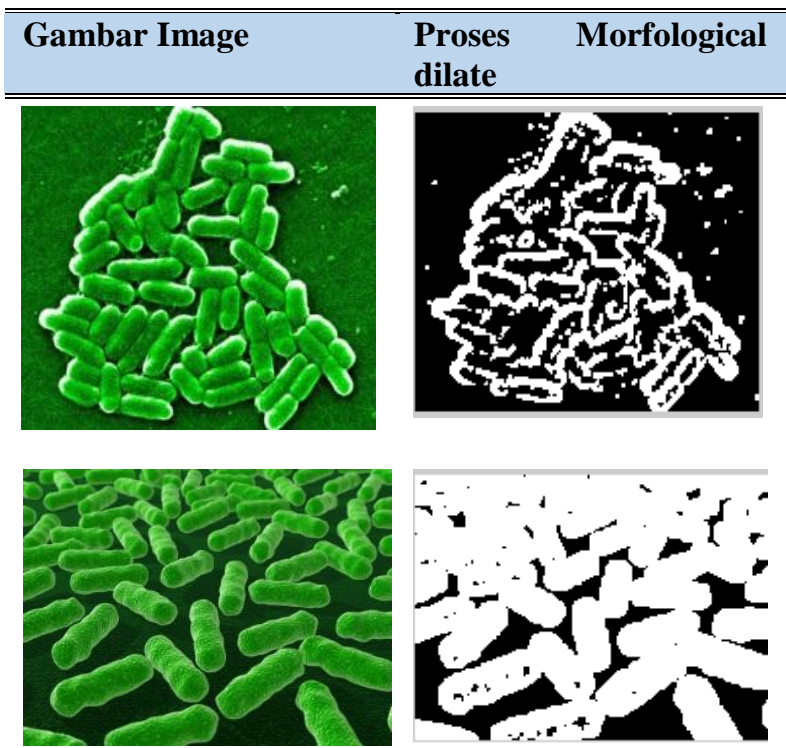



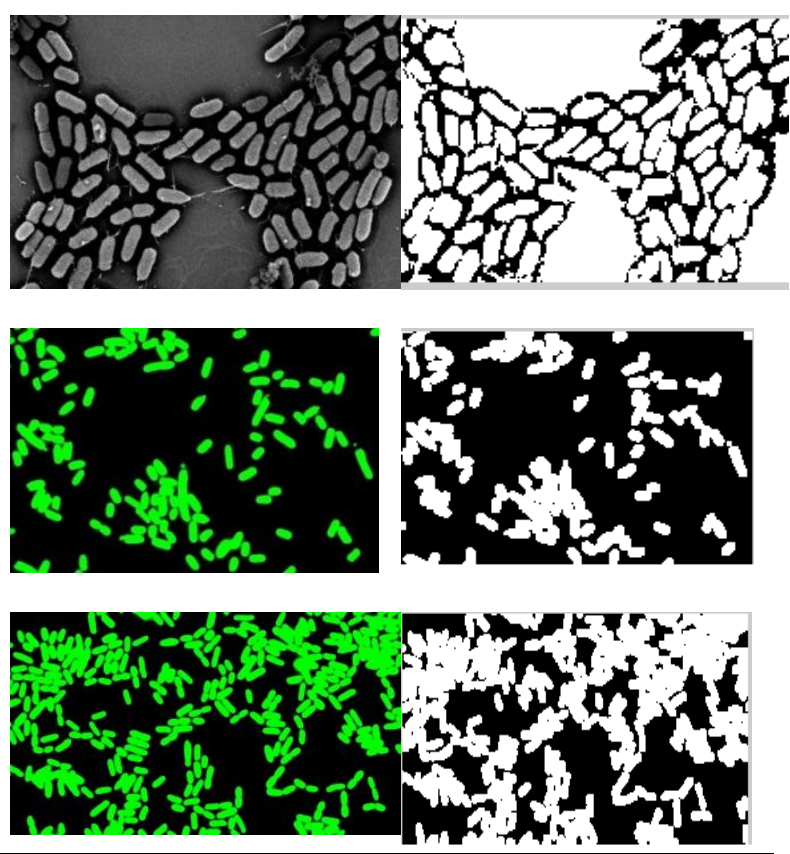

Tabel 2. pengaturan property pada blob Analysis.

\begin{tabular}{ll}
\hline \hline AreaOutputPort & $\begin{array}{l}\text { Penilian variable dengan } \\
\text { nilai True dan False }\end{array}$ \\
CentroidOutputPort & Metode perhitungan \\
& secara acak berdasarkan \\
& kemunculan dari image \\
BoundingBoxOutputPort & Set koordinat dari \\
& bouding dengan nilai set \\
& propoerty True dan False \\
\hline \hline
\end{tabular}

\section{VI.4 Penerapan Metode Mofological Dilate}

Inputan data berupa video bacteria hasil perhitungan bisa dilihat pada tabel 3 dibawah ini dimana jumlah bakteri yang telah dihitung diberi tanda atau marker sehingga oleh sistem

Tabel 3. Perhitungan Jumlah Bacteri

\begin{tabular}{|c|c|c|}
\hline Data image & Data Dilate & $\begin{array}{l}\text { Jumlah } \\
\text { bakteri }\end{array}$ \\
\hline & & $\begin{array}{l}\text { Frame : } 512 \\
\text { Bacteri: } 648\end{array}$ \\
\hline
\end{tabular}
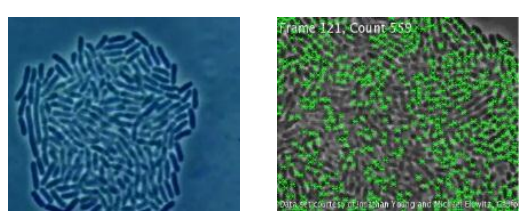

Frame: 125

Bacteria :670

\section{Keterangan :}

Pada tabel diatas menunjukan perhitungan bacteri ecoli dengam sample pertama terhitung 648 bacteri dan sample yang kedua 670 bacteri jumlah frame menunjukan jumlah frame image yang di ambil dari data video.

\section{KESIMPULAN}

Dari hasil percobaan dapat disimpulkan bahwa perhitungan bacteria e-coli dengan menggunakan metode motfological dilate bisa diimplemtasikan dan mengatasi perhitungan secara manual, dengan metode ini maka kita bisa melakukan perhitungan secara tepat dan cepat tentang jumlah perkembangan bacteri $e$-coli dalam suatu bahan makanan bisa digolongkan pada level aman atau bahaya.

Untuk penilitian selanjutnya digunakan data dan sample yang lebih banyak, data bisa berupa vidio atau berupa image dan sistem perhitungan bacteri $e$ coli dibuat dalam bentuk GUI (Grafik User Interface) agar memudahkan pengguna

\section{REFERENSI}

Advantages of Standardized Usability Questionnairres

Amazine12 Fakta dan Informasi Menarik tentang Bakteri e Coli,

Assessing the Reliability, Validity and Adaptability of PSSUQ20059th Americas Conference on Information SystemsOmaha, Nebraska

Bagian-bagian Penyusun Struktur Sel Bakteri dan Fungsinya

Bo Yang Yu; Caglar Elbuken;Carolyn L. Ren; Jan P. HuissoonImage processing and classification algorithm for yeast cell morphology in a 
microfluidic chipJournal of Biomedical Optics 16

C. Zimmer, E. Labruyere; V. Meas-Yedid;N. Guillen; J. C. Olivo-Marin2010Segmentation and tracking of migrating cells in videomicroscopywith parametric active contours:IEEE Trans. Med. Imaging 21(10)1212-122121

Gonzalez, R. C;Woods, R. E.,2002Digital ImageProcessing Second Edition, Pearson EducationNew Jersey

Jiwanjaya Yoga Metode Perhitungan Bakteri

Juwita Usna; Haryani Yuli; Jose Christine2014umlah Bakteri Coliform dan Deteksi Escherichia coli Pada Daging Ayam di Pekanbaru1

Manfaat dan Bahaya E. Coli-Escherichia Coli

O. Dzyubachyk; W. A. van Cappellen; J. Essers;W. J. Niessen;2010Advanced level-set-based cell tracking in time-lapse fluorescence microscopy IEEE Trans. Med. Imaging 291331-1331

Saputra; Rochmat2013Perhitungan Jumlah Mikroba T12: Standardized Usability Questionarry

X.Wang;W. He; D. Metaxas2007Cell segmentation and tracking using texture-adaptive snakes 4th IEEE Int. Symp. on Biomedical Imaging:Macro to Nano (ISBI 2007)1101104 